J. Clin. Chem. Clin. Biochem.

Vol. 14, 1976, pp. 437-441

\title{
Gas Chromatographic Estimation of Homovanillic Acid in Serum of Normals and Psychotic Patients
}

\author{
By E. Markianos and E. Rüther \\ Psychiatrische Klinik (Direktor: Prof. Dr. H. Hippius) der Universität München
}

(Received November 11, 1975/June 9, 1976)

Summary: Homovanillic acid is extracted from $0.5 \mathrm{ml}$ serum with ethyl acetate at acidic $\mathrm{pH}$, and its pentafluoropropionic anhydride and hexafluoroisopropanol derivative injected into a $3 \%$ SE-30 column at $140{ }^{\circ} \mathrm{C}$, fitted with an electron capture detector. In a group of normal volunteers $(n=42)$ a mean value of $62 \pm 45 \mu \mathrm{g} / \mathrm{l}$ was found. The distribution of the serum concentrations was found to be bimodal. Using the same procedure for the homovanillic acid estimation in cerebrospinal fluid (CSF), mean values of $73.0 \pm 41 \mu \mathrm{g} / \mathrm{l}$ serum and $68 \pm 36 \mu \mathrm{g} / \mathrm{l} \mathrm{CSF}$ were found for a group of 22 untreated patients with paranoid-hallucinatory syndrome. After treatment with neuroleptics, for 1 week to 1 month, the homovanillic acid concentration increased significantly only in the CSF. By the procedure described, other acidic metabolites of biogenic amines are extracted together with homovanillic acid and can also be estimated in the same sample.

\section{Gaschromatographische Bestimmung von Homovanillinsäure im Serum Gesunder und psychotischer Patienten}

Zusammenfassung: Homovanillinsäure wird aus $0.5 \mathrm{ml} \mathrm{Serum} \mathrm{mit} \mathrm{Ethylacetat} \mathrm{bei} \mathrm{saurem} \mathrm{pH} \mathrm{extrahiert} \mathrm{und} \mathrm{nach}$ Derivatisierung mit Pentafluorpropionsäureanhydrid und Hexafluorisopropanol auf einer 3\% SE-30 Säule gaschromatographisch getrennt und mit Elektroneneinfangdetektor bestimmt. Für eine Gruppe von Normalpersonen ( $=42)$ wurde ein Mittelwert von $62 \pm 45 \mu \mathrm{g} / 1$ Serum ermittelt, und die Verteilung der Konzentrationen war bimodal. Die gleiche Methode kann für die Homovanillinsäure Bestimmung im Liquor cerebrospinalis angewandt werden. In einer Gruppe psychotischer Patienten mit paranoid-halluzinatorischem Syndrom $(n=22)$, unbehandelt, wurden Mittelwerte von $73 \pm 41 \mu \mathrm{g} / \mathrm{l}$ Serum und $68 \pm 36 \mu \mathrm{g} / \mathrm{l}$ Liquor gefunden. Nach Behandlung mit Neuroleptika kam es zu einer Homovanillinsäure Anstieg nur im Liquor. Die Methode erfaßt außer Homovanillinsäure auch andere saure Metabolite biogener Amine.

\section{Introduction}

Homovanillic acid (4-hydroxy-3-methoxyphenylacetic acid) is considered to be the main metabolite of dopamine in the brain. It has been detected in brain tissue and cerebrospinal fluid (CSF) (1-3) and its concentration in CSF may reflect the central dopamine turnover (for review see 1.c. (4)).

Dopamine is metabolized by the alternative action of monoamine oxidase and catechol-O-methyltransferase; the O-methylated and oxidatively deaminated product, an aldehyde, is further oxidized to the acid by aldehyde dehydrogenase. The $\mathrm{O}$-methylation can take place at the 4-OH group of dopamine, whereby iso-homovanillic acid is produced. It häs been detected in small amounț in CSF $(5,6)$.
An active transport system, sensitive to probenecid, removes homovanillic acid from the brain to CSF and from CSF to the blood (7). It is localized in the region of the fourth ventricle (8). In CSF, there is a gradient in the homovanillic acid concentration: in man, the concentration falls from $466 \mu \mathrm{g} / \mathrm{l}$ in the ventricular CSF to 185 in the cisternal and to $53 \mu \mathrm{g} / \mathrm{l}$ in the lumbar CSF (9). In lumbar CSF, the concentration of homovanillic acid depends greatly on the conditions under which the puncture was performed (position of the patient, restriction of movement for several hours before puncture, amount of fluid taken).

Urinary concentrations of homovanillic acid do not correlate with CSF concentrations (10) and it is still unknown which part of urinary homovanillic acid originates from central dopamine turnover. Its estimation 
in the intermediate fluid, blood, could give further information on dopamine metabolism, especially on changes during pharmacological studies.

Methods of homovanillic acid estimation used until now were based on the fluorimetric determination of homovanillic acid isolated by column chromatography. They were used for the estimation in CSF, brain tissue and urine $(1,7,11,12,13)$. A gas chromatographic method for the estimation of homovanillic acid in CSF has been described (14), using an electron capture detector, following derivatization with pentafluoropropionic anhydride and hexafluoroisopropanol.

We developed a simple and efficient method for the estimation of homovanillic acid in serum, using an appropiate column for its separation from the other serum constituents, which was sensitive enough to allow the estimation in $0.5 \mathrm{ml}$ serum.

We estimated homovanillic acid in the serum of normals, and in the serum and CSF of psychotic patients, before and after treatment with neuroleptics, in order to see how far serum homovanillic acid concentrations reflect eventual changes in dopamine turnover.

\section{Method}

\section{Extraction and derivatization}

$0.5 \mathrm{ml}$ serum is diluted with $1 \mathrm{ml}$ water and $0.1 \mathrm{ml} 1 \mathrm{~mol} / 1 \mathrm{HCl}$ is added to bring the $\mathrm{pH}$ to between 1.5 and $2.0 .3 \mathrm{ml}$ ethyl acetate are added; the mixture is shaken for 5 minutes, then centrifuged to separate the phases. The ethyl acetate phase is removed with a pasteur pipette and the procedure is repeated two more times. The combined extracts are evaporated to dryness in an evapo-mix (Buchler Instr., Fort Lee, U.S.A.). $0.1 \mathrm{ml}$ pentafluoroproponic anhydride and $0.1 \mathrm{ml}$ hexafluoroisopropanol (both from Pierce Chemicals, U.S.A.) are added and incubated for 10 minutes at $60^{\circ} \mathrm{C}$. The excess reagent is evaporated with a gentle nitrogen flow (smell test) and the product dissolved in $1 \mathrm{ml}$ dry ethyl acetate.

\section{Gas chromatography}

$2 \mu \mathrm{l}$ are injected into a gas chromatographic system (HewlettPackard 7602A, with automatic injection system and integrator) with an electron capture detector (nickel) and a coiled glass column 6 feet $\times 4 \mathrm{~mm}$, packed with chromosorb WAW DMCS 80-100 mesh, coated with 3\% SE-30. The column temperature is set at $140^{\circ} \mathrm{C}$, detector and injection port at $180^{\circ} \mathrm{C}$. Carrier gas flow rate $40 \mathrm{ml} / \mathrm{h}$ (helium), argon-methane (10\%) flow rate $40 \mathrm{ml} / \mathrm{h}$. Under these conditions the retention time for homovanillic acid is 6 minutes.

We use the same procedure for the homovanillic acid estimation in CSF, with the only difference that in this case $0.04 \mathrm{ml} \mathrm{HCl}$ are added to bring the $\mathrm{pH}$ to less than 2.0 .

For the calculation of the homovanillic acid concentrations, we use the difference in response (peak height) when authentic homovanillic acid is added in the sample at the beginning of the procedure.

Figure 1 shows a chromatogram of a serum extract with and without internal standard.

\section{Results}

The reproducibility of the method was found to be very good: In a 5 fold estimation we found, using the integrator counts to express the response, a mean value for the homovanillic acid peak of 50,494 $\pm 5,366$ counts, with a range 43,010 to 57,610 counts, and a variation coefficient of $10.6 \%$. The variation in the response of homovanillic acid added as internal standard was found to be of the same order.

After incubation with glusulase to hydrolyze any sulfate or glucuronate conjugates of homovanillic acid that may be present, we found no increase in the amount of homovanillic acid. This indicates that at least $90 \%$ of the serum homovanillic acid is present in the free form.

The recovery of added homovanillic acid was calculated by comparing the response obtained from a certain amount of internal standard with the response of the
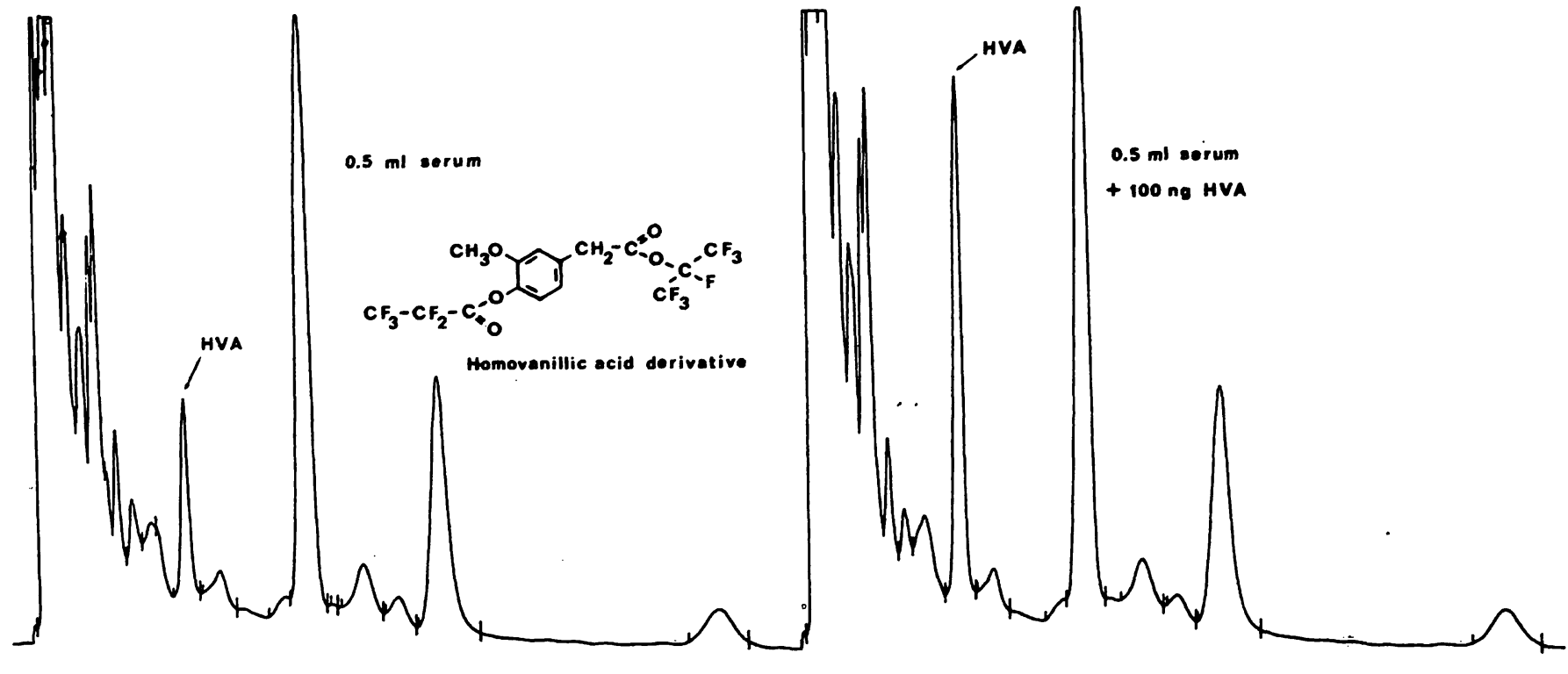

Fig. 1. Gas chromatograms of serum extracts without (a) and with (b) internal standard $(0.5 \mathrm{ml}$ serum +100 ng homovanillic acid). Retention time of homovanillic acid (HVA) $=6 \mathrm{~min}$ 
same amount of homovanillic acid incubated as dry substance and was found to be 70-75 per cent.

Variation of the serum volume from $0.25 \mathrm{ml}$ to $1.0 \mathrm{ml}$ gave a linear correlation to the homovanillic acid response $(r=0.9559)$, and variation of the amount of internal standard from 50 to $200 \mu \mathrm{g} / 1$ gave a linear correlation with $r=0.9790$.

The other acidic metabolites of biogenic amines are extracted and derivatized together with homovanillic acid and must appear in the chromatogram. We found that 3-methoxy-4-hydroxymandelic acid runs in the chromatogram close to and before homovanillic acid. Its response was five times lower than that of homovanillic acid. We found the 3-methoxy-4-hydroxymandelic acid peak only in a small number of the sera analyzed. In general, the serum concentration of 3 methoxy-4-hydroxymandelic acid seems to be lower than $20 \mu \mathrm{g} / 1$, and the same is true for CSF.
5-Hydroxyindolylacetic acid, the main metabolite of serotonin, can be estimated by the same procedure. The column temperature must be set higher, at $190^{\circ} \mathrm{C}$, to get a retention time of about 6 minutes. It is detected with about the sensitivity as homovanillic acid. Thus, after the injection of the samples at $140^{\circ} \mathrm{C}$ for the homovanillic acid estimation, the same samples can be injected once more at $190^{\circ} \mathrm{C}$ for 5-hydroxyindolylacetic acid.

Homovanillic acidin serum of normals

We analyzed the sera of 42 normal volunteers, men and women, aged between 22 and 60 years. A mean value of $62 \pm 45 \mu \mathrm{g} / \mathrm{l}$ was found for the group, with a range from 7 to 186 . The mean value corresponds to $340 \pm 247$ $\mathrm{nmol} / \mathrm{l}$ serum ( $1 \mu \mathrm{g} / \mathrm{l}$ corresponds to $5.49 \mathrm{nmol} / \mathrm{l}$, and for comparison with literature values, to $1 \mathrm{ng} / \mathrm{ml}$ ). The histogram revealed a bimodal distribution of the homo-
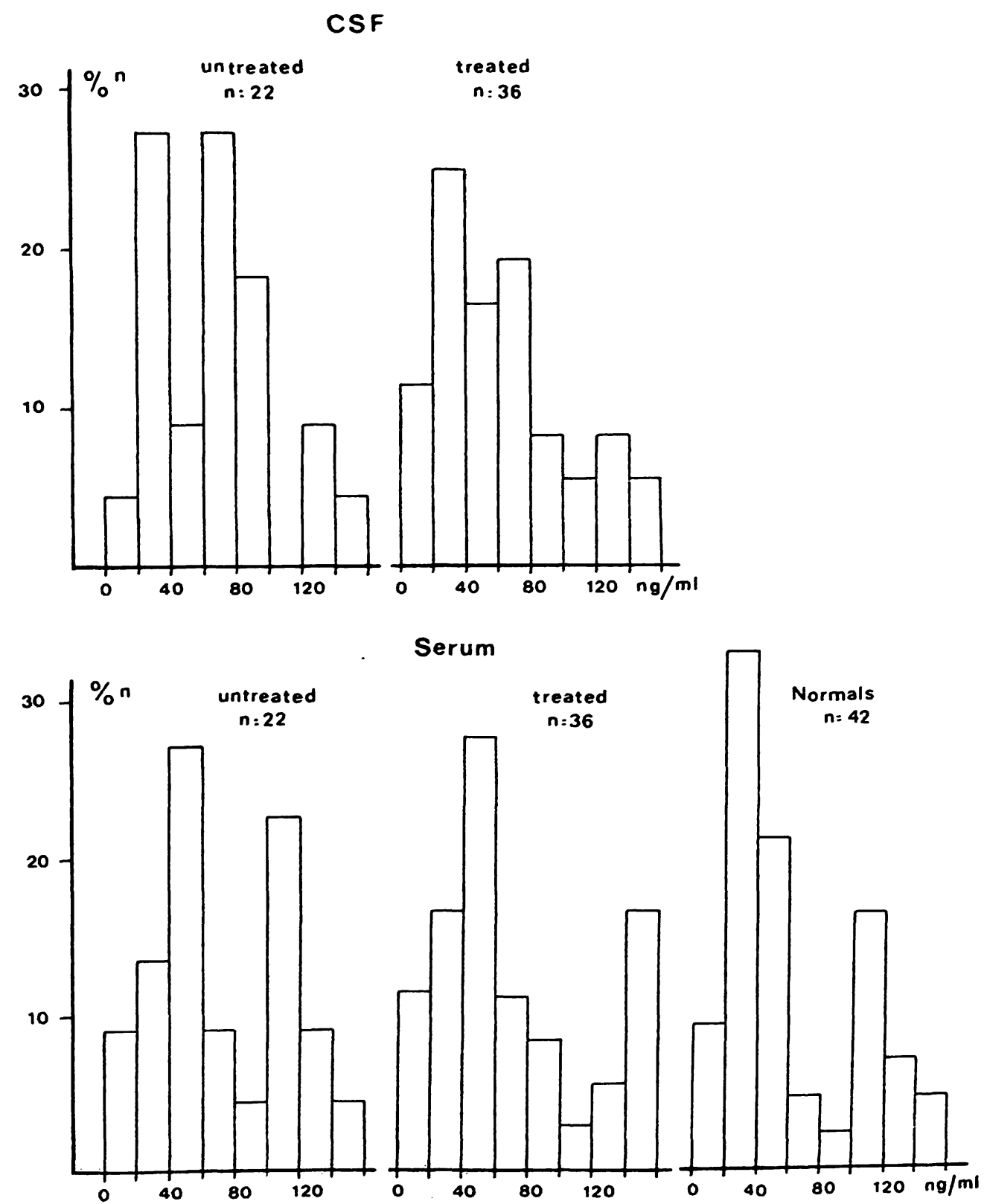

Fig. 2. Distribution of homovanillic acid concentrations in cerebrospinal fluid and serum of the groups. 
vanillic acid concentrations in the group, with a peak between 20 and $60 \mu \mathrm{g} / \mathrm{l}$ (54.7\% of the population) and a second one, smaller, with concentrations over $100 \mu \mathrm{g} / \mathrm{l}$ (28.4\% of the population) (fig. 2). This kind of distribution is responsible for the great variation coefficient found for the group $(\mathrm{CV}=73 \%)$.

Homovanillic acid in serum and CSF of psychotic patients

In a number of psychotic patients with paranoid-hallucinatory syndrome, hospitalized in our clinic, lumbar punctures were performed for routine analysis and estimation of catecholamine metabolites in CSF. The cerebrospinal fluid was collected in portions $(0.5,2,2,7,2 \mathrm{ml})$, the patient being in a sitting position, and stored immediately at $-20^{\circ} \mathrm{C}$ until analysis. After the puncture $10 \mathrm{ml}$ blood were taken and the serum separated by centrifugation. We estimated homovanillic acid in the serum and in the last CSF portion.

Table 1 shows the results of the homovanillic acid estimations. Group II refers to a group of psychotic patients with paranoid-hallucinatory syndrome who were not under neuroleptic treatment when the CSF and blood samples were taken. Group III is a group of patients with the same symptomatology who were under treatment with neuroleptics for a longer period, at least one month. And group IV refers to 10 patients from the group II, who were then treated in our clinic with haloperidol; their CSF and blood were sampled again after one month.
For the statistical evaluation of the results, we used the Wilcoxon test for the small group IV, and the Student t-test and linear regression test for the other groups. The results are shown in table 2.

The homovanillic acid concentrations in the sera from the group of untreated patients did not differ from those in the sera from the group of normals. In both, the distribution was bimodal (fig. 2). Significantly higher concentrations were found for the group of chronically treated patients, compared to the group of normals. Significantly elevated homovanillic acid concentrations were also found in the CSF but not in serum after short time treatment with neuroleptics. Thus, it can be postulated that short-term treatment elevates the homovanillic acid concentrations in CSF, while longterm treatment elevates homovanillic acid in serum. This could be an indication for some inhibition of homovanillic acid transport from CSF to blood caused at the beginning of the treatment with neuroleptics, parallel to the known effect of increase in dopamine turnover.

The correlation between homovanillic acid concentrations in serum and in CSF was tested by the linear regression test and Spearman's correlation coefficient. No significance was found for any group. We did not estimate homovanillic acid in CSF of normals, so that the question of whether there is a correlation normally cannot be answered.

Tab. 1: Homovanillic acid concentrations $(\mu \mathrm{g} / \mathrm{l})$ in serum of normals and in serum and CSF of psychotic patients.

\begin{tabular}{llcccc}
\hline & \multicolumn{2}{c}{ Serum } & & CSF \\
Group & N & mean \pm S.D. & range & mean \pm S.D. & range \\
\hline I Normals & 42 & $62.1 \pm 45.5$ & $7-186$ & - & - \\
II Patients, untreated & 22 & $73.0 \pm 41.5$ & $18-162$ & $68.3 \pm 36.1$ & $18-150$ \\
III Patients, chronically treated with & & & & & \\
neuroleptics & 36 & $80.7 \pm 68.5$ & $13-283$ & $65.1 \pm 42.9$ & $10-185$ \\
IV Patients before treatment with haloperidol & 10 & $68.5 \pm 31.8$ & $32-117$ & $61.3 \pm 43.7$ & $22-150$ \\
after treatment with haloperidol for 7-30 days & 10 & $85.7 \pm 71.9$ & $23-208$ & $85.2 \pm 46.9$ & $40-185$ \\
\hline
\end{tabular}

Tab. 2. Statistical evaluation of the results mentioned in Table 1.

\begin{tabular}{lllc}
\hline Reference group & compared to & test & significance \\
\hline Normals, serum & group II, serum & t-test & $t=+1.2378$ n.s. \\
Normals, serum & group III, serum & t-test & $t=+1.7244 .0 .05$ \\
Group IV, serum, before treatment & group IV, serum, after treatment & Wilcoxon & n.s. \\
Group IV, CSF, before treatment & group IV, CSF, after treatment & Wilcoxon & 0.05 \\
Group II, serum & group II, CSF & Spearman & $\mathrm{r}=-0.2048$ n.s. \\
Group III, serum & group III, CSF & Spearman & $\mathrm{r}=+0.1851$ n.s. \\
Group IV, serum, before treatment & group IV, CSF, before treatment & Spearman & $\mathrm{r}=+0.4121$ n.s. \\
Group IV, serum, after treatment & group IV, CSF, after treatment & Spearman & $\mathrm{r}=0.0000$ \\
\hline
\end{tabular}




\section{References}

1. Andén, N. E., Roos, B. E. \& Werdinius, B. (1963), Life Sci., 2, 448-458.

2. Andén, N. E., Roos, B. E. \& Werdinius, B. (1963), Experientia, 19, 359-360.

3. Sharman, D. F. (1963), Brit. J. Pharmac. Chemother., 20, 204-213.

4. Garelis, E., Young, S. N., Lal, S. \& Sourkes, T. L. (1974), Brain Res., 79, 1-8.

5. Mathieu, P., Revol, L. \& Trouillas, P. (1972), J. Neurochem., $19,81-86$.

6. Dziedzic, S. W. \& Gitlow, S. E. (1974), J. Neurochem., 22, 333-335.

7. Gildberg, H. C., Ashcroft, G. W. \& Crawford, T. B. B. (1966), Life Sci., S, 1571-1575.

8. Ashcroft, G. W., Dow, R. C. \& Moir, A. T. B. (1968), J. Physiol., (Lond.), 199, 397-425.
9. Moir, A. T. B., Ashcroft, G. W., Crawford, T. B. B. Eccleston, D. \& Guldberg, H. C. (1970), Brain, 93, 357-368.

10. Ackenheil, M., Beckmann, H., Hoffmann, G., Markianos, E., Nyström, I. \& Raese, J. (1974) Arzneim.-Forsch. (Drug Res.), 24, 984-987.

11. Sato, T. L. (1965), J. Lab. Clin. Med., 66, 517-525.

12. Gerbode, F. A. \& Bowers, M. B. (1968), J. Neurochem., 15, 1053-1055.

13. Ashcroft, G. W. \& Sharman, D. F. (1962), Brit. J. Pharmac., 19, 153-158.

14. Dziedzic, S. W., Bertani, L. M., Clarke, D. D. \& Gitlow, S. E. (1972), Analyt. Biochem., 47, 592-600.

15. Gottfries, C. G., Gottfries, I. \& Roos, B. E. (1969), J. Neurochem., 16, 1341-1345.

Dr. E. Markianos

Psychiatrische Klinik der Universität München Neurochemische Abteilung

Nussbaumstr. 7

D-8000 München 2 
